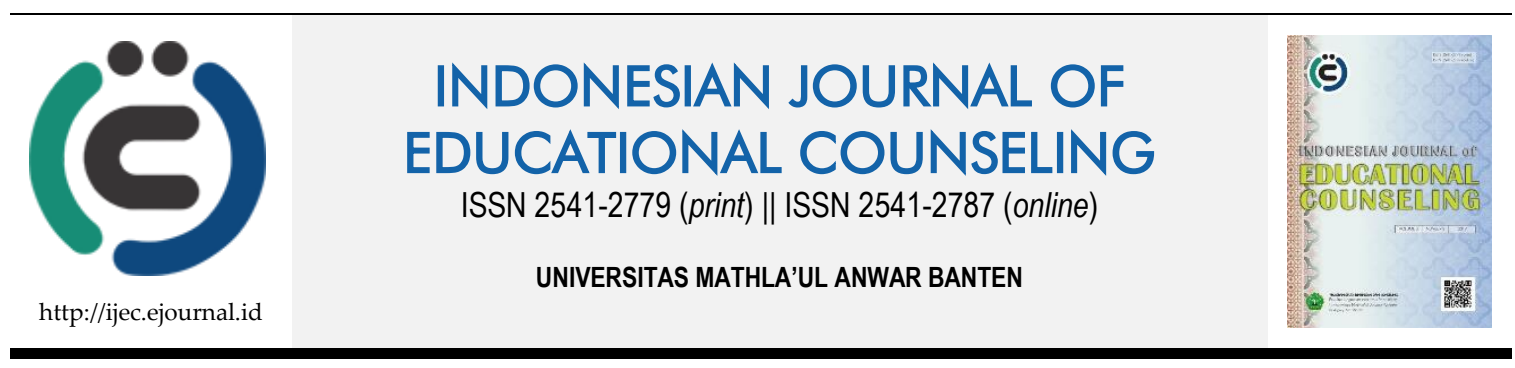

Research Based Article

\title{
Layanan Bimbingan Kelompok dengan Pendekatan Kolaboratif untuk Meningkatkan Kemampuan Perencanaan Karier Siswa SMK
}

\author{
Kristiani $^{1,2}$, Happy Karlina Marjo ${ }^{2}$, Lara Fridani ${ }^{2}$ \\ ${ }^{1}$ SMKN 29 Jakarta, ${ }^{2}$ Universitas Negeri Jakarta
}

\begin{tabular}{ll}
\hline Article History & ABSTRACT \\
\hline Received: 04.04.2019 & GROUP GUIDANCE SERVICES WITH A COLLABORATIVE APPROACH TO \\
Received in revised form: & IMPROVE CAREER PLANNING ABILITY IN VOCATIONAL STUDENTS. \\
Accepted: 02.07 .2019 & This study aims to improve career planning through Guidance Groups in AP-1 \\
Available online: 23.07.2019 & Class XI Students of 29 Jakarta Vocational School Odd Semester 2018/2019 \\
& Academic Year. After analyzing can be found more deeply, two factors can \\
& because, namely internal factors and external factors. Internal factors are the \\
& factors related to the guidance teacher as the implementer of counseling, \\
& including the skills and attitudes of the counselor. Guiding skills are the main \\
& factor in the success of counseling at school. External factors are factors that \\
& come from outside the supervise of the teacher, including the principal's \\
& policies, and students' knowledge and understanding of counseling. The \\
problem examined in this study is how to improve the material guidance, & service of career and to plan through group guidance methods can improve \\
& students' communication skills as a variable y while consulting service \\
guidance as a variable x. Communication skills improvement was measured & through questionnaires that contained interest in counseling, counseling, \\
& understanding of BK, trust in BK and attitudes towards counseling stating that \\
students' interest in counseling would increase through group guidance \\
methods arranged according to the sequence of student interests that could be \\
verified. \\
KEYWORDS: Career Planning, Group Guidance, Interest in Counseling.
\end{tabular}

DOI: $10.30653 / 001.201932 .92$

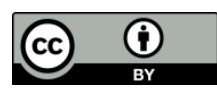

This is an open access article distributed under the terms of the Creative Commons Attribution 4.0 International License, which permits unrestricted use, distribution, and reproduction in any medium, provided the original work is properly cited. ๔ 2019 Kristiani, Happy Karlina Marjo, Lara Fridani.

\section{PENDAHULUAN}

Menentukan pilihan karier yang sesuai dengan kepribadian yang dimiliki invididu merupakan hal yang penting untuk diperhatikan. Ginzberg (1972) mengemukakan bahwa proses pemilihan karier membutuhkan waktu karena proses ini bukan hanya terbatas pada satu-satu jangka waktu tertentu tetapi merupakan sesuatu proses yang 
berkelanjutan seumur hidup seseorang dalam dunia pekerjaannya. Pemilihan karier seseorang dipengaruhi oleh beberapa faktor diantaranya faktor realitas; yaitu pemilihan suatu pekerjaan adalah akibat dari tekanan lingkungan, kemudian faktor proses pendidikan; karena bidang karier ditentukan oleh kualitas dan kuantitas pendidikan yang diperoleh seseorang, faktor emosi;pemilihan karier tergantung pada aspek kepribadian seseorang, dan faktor nilai pribadi;merupakan faktor yang menentukan jenis pekerjaan yang akan dipilih oleh seseorang (Ginzberg, 1972).

Holland menyebut bahwa dalam memilih karier, seseorang lebih suka pekerjaan di mana individu dapat berada di sekitar orang lain yang memiliki kesamaan dalam minat aktivitas tertentu (Adriyanto, 2012). Hal tersebut dikarenakan adanya interaksi baik berupa interaksi individu dengan dirinya ataupun interaksi individu dengan lingkungannya, hal tersebut akan mempengaruhi kompetensi individu dan perilaku sosialnya, yang pada akhirnya akan membentuk dan mengarahkan individu dalam menentukan pilihannya dalam berkarier, baik dalam menentukan lanjutan pendidikannya maupun pilihan pekerjaan yang akan dijalaninya. Individu akan mencari lingkungan yang dapat mengoptimalkan penggunaan keterampilan dan kemampuannya, mengekspresikan sikap dan nilai-nilai, dan pada saat bersamaan menikmati masalah dan peran secara menyenangkan. Dengan adanya kesesuaian antara tipe kepribadian dengan lingkungan akan mengoptimalkan perkembangan siswa dalam menempuh jenjang kariernya, selain itu siswa akan memperoleh kepuasan psikilogis dalam menjalani karier dalam kehidupannya. Sehingga menimbulkan tanggung jawab lebih tinggi terhadap pekerjaannya yang membuat individu lebih giat dalam menjalani pekerjaannya dan berdampak pada kemajuan jenjang kariernya.

Pemahaman individu mengenai kepribadian berpengaruh pada kesuksesan kariernya, karena dengan memahami keribadiannya maka akan mengarahkan pada pilihan karier yang sesuai dengan dirinya. Dalam teorinya Holland mengemukakan bahwa tingkatan orientasi individu akan menentukan lingkungan kerja yang dipilihnya, semakin jelas tingkatannya, maka semakin efektif dalam menentukan lingkungan yang sesuai (Manrihu, 1992, p. 71). Pada siswa di Sekolah Menengah Kejuruan (SMK) berada pada masa remaja, adapun salah satu tugas perkembangan yang harus dicapainya adalah memilih dan mempersiapkan diri untuk menjalankan suatu pekerjaan. Menurut Hurlock (1980, hal 10) pemilihan dan persiapan untuk menjalankan suatu pekerjaan merupakan tugas perkembangan yang penting dimasa remaja, karena karier seseorang menentukan berbagai hal dalam kehidupan. Dengan pemahaman siswa mengenai kepribadiannya maka akan membantu siswa dalam memilih dan merencanakan kariernya sesuai dengan minatnya. Barret (2004, p. 172) mengemukakan bahwa kesesuaian kepribadian siswadengan lingkungan akademis yang ditempati berpengaruh positif terhadap prestasi akademis dan kestabilan perjalanan kariernya.

Suatu lingkungan pekerjaan akan didominasi oleh suatu tipe kepribadian tertentu, hal tersebut berkaitan dengan peluang yang diberikan oleh setiap lingkungan. Holland mengkategorikannya dalam enam tipe kepribadian, yaitu realistic, investigative, social, enterprising, artistic dan conventional. Setiap tipe memliki pola interaksi dan kompetensinya masing-masing, keterampilan dalam mengatasi suatu masalah dalam lingkungan pekerjaannya akan bergantung dengan bagaimana individu memproses suatu informasi sehingga menghasilkan penyelesaian yang beragam. Misalnya, lingkungan konvensional tidak akan didominasi oleh tipe artistik melainkan didominasi 
oleh tipe konvensional pula. Hal tersebut dikarenakan setiap model lingkungan akan menciptakan suatu lingkungan yang mencerminkan identitasnya.

Hasil penelitian Kristiani et al. (2018, p. 14) di SMKN 29 menyatakan bahwa 75\% siswa mengambil keputusan karier berdasarkan kesempatan, dan hanya 55\% siswayang sudah mempersiapkan diri untuk menentukan pilihan karier. Sedangkan untuk pengambilan keputusan karier yang disesuaikan dengan minat dan kepribadiannya hanya $65 \%$ peserta didik. Menurut penelitian yang dilakukan Kritiani dkk pada tahun 2018 di SMKN 29 di Jakarta, menggambarkan 65\% siswa kelas XI AP sudah mempunyai pilihan pekerjaan dan profesi, sementara $45 \%$ belum memiliki pilihan pekerjaan dan profesi.

Data di atas menunjukkan bahwa pemilihan karier siswa yang didasarkan pada karakteristik kepribadiannya masih belum optimal. Masalah yang dominan terjadi karena kurang optimalnya pemberian layanan bimbingan karier pada peserta didik, sehingga sebagian besar siswa kurang mengeksplor pekerjaan-pekerjaan yang sesuai dengan potensinya yang menyebabkan siswa kurang tepat untuk memilih kelanjutan kariernya dan pemilihan karier hanya didasari dengan kesempatan yang ada saja. Selain itu, karena kurangnya informasi mengenai karier pada siswa yang menyebabkan masih banyak siswa yang belum merencanakan kariernya secara matang, sehingga hal tersebut menjadi salah satu hambatan untuk siswa memutuskan kariernya di masa depan secara optimal. Dalam hal ini proses bimbingan dan konseling sangat dibutuhkan untuk memfasilitasi siswa agar mampu memahami, menyadari serta menghargai potensi dalam dirinya yang dapat dikembangkan menjadi suatu kekuatan yang dapat membuat dirinya lebih percaya diri dan tepat dalam menentukan kariernya dimasa mendatang.

Berdasarkan fenomena dan berbagai indikator mengenai kecenderungan pemilihan karier yang kurang optimal pada siswa, maka pelaksanaan layanan bimbingan karier sangat diperlukan. Pemilihan karier yang kurang optimal dapat mempengaruhi pilihan karier peserta didik, yang menyebabkan kurang optimalnya eksplorasi informasi untuk melakukan pilihan karier. Sementara, pengambilan keputusan karier yang kurang tepat dapat mempengaruhi keberhasilan peserta didik. Untuk itu penting memberikan layanan bimbingan karier agar dapat memfasilitasi siswa dalam membuat perencanaan kariernya dan mengambil keputusan secara tepat. Dengan demikian siswa tidak lagi merasa kesulitan ataupun kebingungan untuk mengambil keptusan untuk kariernya dimasa mendatang.

Penelitian ini membahas mengenai perencanaan dan pemilihan karier siswa yang disesuaikan dengan potensi yang dimilikinya, dengan cara memberikan fasilitas pada siswa untuk mampu memahami kondisi dirinya, khususnya berkaitan dengan kepribadian dan minatnya. Dengan demikian siswa mampu mengidentifikasi karakteristik kepribadiannya dan mengidentifikasi potensi yang dimilikinya, sehingga dapat merencanakan dan melakukan pilihan karier secara tepat.

Terdapat berbagai permasalahan karier yang berkenaan dengan kesesuaian tipe kepribadian dengan pilihan karier, karena itu dibutuhkan upaya dalam menanggulanginya, salah satunya dengan melakukan analisis terlebih dahulu terhadap kesesuaian antara kepribadian dan pilihan karier peserta didik. Secara umum berdasarkan latar belakang, permasalahan penelitian mencakup bagaimana profil kecenderungan pemilihan karier peserta didik, khususnya siswa Sekolah Menengah 
Kejuruan (SMK) yang sejak awal sudah diarahkan pada kemampuan masing-masing jurusan. Secara rinci indikator masalah pemilihan karier siswa mencakup hal-hal mengenai kurang optimalnya pemberian layanan bimbingan karier pada siswa yang berdampak pada kurangnya informasi mengenai karier yang didapatkan oleh peserta didik, kurang mantapnya arah keputusan dalam perencanaan karier sehingga mudah dipengaruhi oleh saran dari guru dan orang tua yang menyebabkan ketakutan siswa jika siswa memilih karier diluar saran dari orang tua dan guru akan gagal, dan siswa masih bingung dengan apa yang harus dia lakukan, hal tersebut dikarenakan siswa masih belum bisa sepenuhnya mengidentifikasi kekuatan dan kelemahan dalam dirinya termasuk hal seperti apa yang sesuai dengan kepribadiannya.

Berdasarkan latar belakang dan identifikasi masalah di atas, maka rumusan masalah yang diajukan, yaitu: Apakah melalui pelayanan bimbingan kelompok dapat meningkatkan kempuan perencanaan karier pada siswa kelas XI AP-1 SMKN 29 Jakarta semester ganjil tahun pelajaran 2018/2019?

\section{METODE}

Penelitian ini menggunakan metode Penelitian Tindakan Kelas (PTK) atau Classroom Action Research yang bertujuan untuk memperbaiki efektivitas dan efisiensi proses pembelajaran. Penelitian Tindakan Kelas merupakan strategi pemecahan masalah yang berfungsi untuk mengambil perencanaan karier siswa. Dalam penelitian ini menggunakan metode pelayanan bimbingan kelompok. Tindakan ini dilakukan kepada orang yang sama dan bekerja sama dengan kolaborator.

Penelitian dilakukan pada semester genap tahun pelajaran 2018/2019 dari bulan Juli 2018 sampai dengan Oktober 2018 yang terdiri dari dua siklus. Tempat penelitian yaitu di SMKN 29 Jakarta yang beralamat di Jalan Prof. Jokosutono, SH No. 1 Kebayoran Baru Jakarta Selatan, DKI.

Subyek penelitian Tindakan Kelas ini adalah semua siswa kelas XI AP1 Tahun Pelajaran 2018/2019 semester II yang berjumlah 36 siswa berjenis kelamin laki-laki. Berdasarkan asesmen awal, kemampuan subjek penelitian dalam perencanaan karier masih rendah. Kondisi lain yang terlihat dari suku atau etnis agama maupun ekonomi, sehingga secara keseluruhan subjek penelitian cukup heterogen.

Kegiatan PTK bimbingan dan konseling dilaksanakan dalam dua siklus, tiap siklus tiga kali pertemuan. Metode yang digunakan dalam bimbingan dan konseling adalah metode bimbingan kelompok. Alasan menggunakan metode bimbingan kelompok tersebut, bahwa metode ini cocok untuk digunakan dalam proses bimbingan dan konseling untuk keberanian siswa berbicara tampil di depan kelas akan meningkat.

Keberanian siswa kurang dalam bertanya maupun mengungkapkan gagasan pada saat tanya-jawab kemungkinan karena kurangnya pemahaman siswa terhadap materi atau karena siswa menganggap ada hal-hal yang dianggap tabu. Oleh guru pembimbing (BK) terhadap siswa yang demikian diberikan layanan bimbingan kelompok. 


\section{HASIL DAN PEMBAHASAN}

Guru Pembimbing Konseling (BK) pada siklus I menyampaikan materi dan memberi kesempatan pada siswa untuk bertanya yang kemudian pertanyaann tersebut dilemparkan pada siswa lain untuk menjawabnya. Pada siklus II guru membagi kelompok-kelompok untuk memberikan layanan bimbingan dan konseling melalui metode kelompok hal yang dibuatnya untuk lebih meningkatkan keberanian siswa dalam mendiskusikan materi perencanaan karier dalam kelompoknya. Guru mengamati aktivitas siswa selama proses diskusi berlangsung dalam kelompok, setelah berdiskusi kelompok, kemudian hasilnya dilaporkan di depan kelas, memberikan waktu kepada kelompok lain untuk menanggapi hasil laporan, tanya jawab, dengan bahasa yang dapat dipahami oleh temannya.

Hasil penelitian menunjukkan perencanaan karier siswa kelas XI AP 1 Jakarta tahun pelajaran 2018/2019 mencapai 65\% berada pada kategori tinggi,, sebesar 20\% berada pada kategori sedang dan $15 \%$ berada pada kategori rendah. Secara lebih rinci gambaran perencanaan karier mahasiswa disampaikan dalam Tabel 1.

Tabel 1. Gambaran Perencanaan Karier Siswa Kelas XI AP 1 Jakarta

\begin{tabular}{lc}
\hline Kriteria & Persentase \\
\hline tinggi & 65 \\
\hline sedang & 20 \\
\hline rendah & 15 \\
\hline Jumlah & 100 \\
\hline
\end{tabular}

\section{Gambaran Perencanaan Karier Siswa: Siklus I}

Pada aspek sikap terhadap pilihan karier dalam bidang profesi kependidikan dua indikator berada pada kategori tinggi yaitu: indikator orientasi sebesar $80 \%$. Indikator keterlibatan sebesar $40 \%$, indikator kemampuan untuk bekerjasama/kompromi sebesar $45 \%$, dan indikator penentuan keputusan sebesar $45 \%$ berada pada kategori sedang dan indikator kemandirian, sebesar 7\% berada pada kategori rendah.

Tabel 2. Gambaran Perencanaan Karier Aspek Sikap

\begin{tabular}{llc}
\hline Indikator & Kategori & Persentase \\
\hline Orientasi & Tinggi & 80 \\
\hline keterlibatan & Sedang & 40 \\
\hline Kerjasama & Sedang & 45 \\
\hline Penentuan keputusan & Sedang & 45 \\
\hline Kemandirian & Rendah & 7 \\
\hline
\end{tabular}

Pada aspek Kompetensi karier siswa dalam memilih karier pada bidang profesi kependidikan menggambarkan kategori tinggi. Indikator pemahaman diri, sebesar $85 \%$, serta penguasaan informasi pekerjaaan sebesar $56 \%$, dan indikator pemilihan pekerjaan berada pada kategori sedang sebesar $42 \%$, serta indikator perencanaan pekerjaan sebesar $12 \%$, dan indikator pemecahan masalah $15 \%$ berada pada kategori rendah. 
Tabel 3. Gambaran Perencanaan Karier Mahasiswa Aspek Kompetensi

\begin{tabular}{llc}
\hline Indikator & Kategori & Persentase \\
\hline Pemahaman diri & Tinggi & 85 \\
\hline Informasi pekerjaan & Sedang & 56 \\
\hline Pemilihan pekerjaan & Sedang & 42 \\
\hline Perencanaan pekerjaan & Rendah & 12 \\
\hline Pemecahan masalah & Rendah & 15 \\
\hline
\end{tabular}

Secara umum siswa berada pada kategori sedang atau kurang dalam kariernya. Hal tersebut ditunjukkan dengan sikap yang ragu-ragu terhadap pekerjaan dalam bidang profesi kependidikan dan belum mampu menguasai pemilihan pekerjaan dalam bidang profesi kependidikan.

\section{Hasil Uji Efektivitas: Siklus II}

Hasil uji efektivitas perencanaan karier siswa menunjukkan bahwa model bimbingan kelompok yang diimplementasikan mampu meningkatkan perencanaan karier siswa. Keefektifan penelitian ini tentunya tidak datang secara tiba-tiba melainkan melalui proses riset. Keberhasilan penelitian ini didukung oleh adanya studi kebutuhan (need assesment) terhadap kebutuhan siswa dalam perencanaan kariernya. Melalui studi pendahuluan yang sudah dilakukan, guru memahami bahwa kegiatan bimbingan bukanlah kegiatan insidentil semata, yang hanya dilaksanakan jika siswa menghadapi masalah, akan melakukan kajian tentang berbagai kebutuhan siswa dan juga studi terhadap berbagai kebutuhan orang tua terhadap pendidikan anaknya.

Bimbingan kelompok ini secara efektif membantu siswa pada perencanaan karier ke arah yang lebih mantap, dikarenakan adanya evaluasi, baik dari siswa, guru maupun oleh orang tua itu sendiri. Evaluasi yang dimaksud dapat berupa evaluasi proses pelaksanaan rencana tindakan per minggu bagi guru dan siswa di SMKN 29 Jakarta dan evaluasi terhadap pengisian lembar kerja siswa di rumah oleh orang tua. Evaluasi penting dilakukan oleh berbagai pihak dalam pelaksanaan bimbingan untuk melihat sejauh mana kualitas keberhasilan model bimbingan.

Pada akhirnya, model bimbingan kelompok dapat diterapkan untuk membantu siswa dalam perencanaan karier yang lebih mantap sebagai bagian dari perencana karier. Pelaksanaan model ini memenuhi harapan Jones (2010) yang mengharapkan hendaknya perencanaan karier membantu siswa mengembangkan keterampilan pengambilan keputusan dan keterampilan lainnya yang diperlukan untuk sukses pada tahapan selanjutnya. Melalui bimbingan kelompok siswa dibantu untuk mencapai potensi mereka sepenuhnya untuk menjadi siswa yang efektif, warga yang bertanggung jawab, dan produktif.

Pendidikan saat ini menuntut adanya kolaborasi dengan berbagai pihak dalam berbagai kegiatan pendidikan. Kolaborasi adalah kegiatan dimana terjadi kerjasama antara berbagai pihak dalam mewujudkan tujuan pendidikan, baik pihak dari dalam maupun dari luar lembaga pendidikan (Nugraha \& Rahman, 2017). Program bimbingan dan konseling sekolah juga menekankan adanya kolaborasi. Adapun kolaborasi dalam bimbingan itu sendiri melibatkan berbagai stakeholder, dari pimpinan sekolah, koordinator BK, guru BK, guru mata pelajaran, guru wali kelas, staf administrasi, komite 
sekolah, sampai dengan orang tua. Orang tua sejatinya merupakan pendidik utama bagi siswa ketika berada di luar lingkungan sekolah. Orang tua terlibat dalam proses komunikasi timbal balik tentang program BK dan perkembangan peserta didik. Orang tua juga membantu dalam pengumpulan data dan informasi, serta membantu kesuksesan layanan BK dengan monitoring di luar sekolah.

Penelitian menunjukkan bahwa keterlibatan orang tua dalam pendidikan anak khususnya melalui interaksi pada sekolah seperti open house, parenting, dan pameran karier memiliki hubungan yang positif dengan keberhasilan siswa. Keluarga adalah tempat lahirnya benih generasi berkarakter dan sekolah adalah tempat tumbuh kembangnya generasi tersebut. Mengingat peran orang tua sebagai pendidik terpenting dalam masa tumbuh kembang anak, maka orang tua adalah mitra sejati bagi pendidik. Sebagai orang tua, tidak cukup hanya berdiri di luar pagar sekolah mengamati proses pendidikan anak-anak kita dari jauh. Tentu perlu kerja keras dari dua sisi. Kolaborasi yang aktif dan positif antara orang tua dan guru BK untuk menyukseskan dan menyelaraskan program pendidikan yang dikembangkan sekolah. Keterlibatan keluarga dalam proses sekolah lanjutan dan eksplorasi karier merupakan kontribusi penting bagi pembangunan pendidikan dan karier remaja yang positif.

\section{SIMPULAN}

Hasil penelitian menunjukkan bahwa metode bimbingan kelompok dapat meningkatkan perencanaan karier siswa. Penelitian ini adalah dapat dijadikan acuan untuk membuat program bimbingan karier yang lebih baik lagi, dan menjadi bahan pertimbangan untuk melaksanakan bimbingan karier dalam mengoptimalkan pengambilan keputusan karier siswa. Oleh karena itu guru bimbingan dan konseling (BK) diharapkan untuk terus bereksplorasi dalam menemukan strategi yang efektif guna meningkatkan kemampuan siswa terhadap materi perencanaan karier siswa, sesuai tingkat kebutuhan siswa, baik di bimbingan dan konseling, maupun di mata pelajaran lainnya.

Sementara seperti yang ditunjukkan dalam temuan lain, bahwa pendekatan kolaboratif dapat menjadi kontribusi penting dalam penyelenggaraan program BK di sekolah secara efektif dan efisien. Dengan demikian keterlibatan berbagai pihak terkait (stakeholder), khususya orang tua dapat memberikan dukungan serta hal positif bagi perkembangan siswa di sekolah, dalam hal ini adalah perencanaan karier siswa yang lebih optimal.

\section{REFERENSI}

ABKIN. (2007). Penataan pendidikan profesional konselor dan layanan bimbingan dan konseling dalam jalur pendidikan formal. Bandung: Asosiasi Bimbingan dan Konseling Indonesia.

Afdal. (2015). Model bimbingan karier kolaboratif dalam memantapkan perencanaan karier siswa $S M A$. (Unpublished doctoral's disertation) Universitas Pendidikan Indonesia, Bandung, Indonesia. 
Anggraini, K. S. (2012). Gambaran perencanaan karier pada mahasiswa yang meingikuti unit kegiatan mahasiswa di Universitas Sumatera Utara. Jurnal Psikologi Indonesia, $1(1), 23-28$.

Crites, J. O. (1981). Career counseling: Models, methods, and materials (Vol. 30, no 2). New York: McGraw-Hill Book Company.

Dimyati, \& Mudjiono. (2006). Belajar dan pembelajaran. Jakarta: Rineka Cipta.

Ginzberg, E. (1972). Toward a theory of occupational choice: A restatement. Vocational Guidance Quarterly, 20(3), 2-9.

Nugraha, A., \& Rahman, F. A. (2017). Strategi kolaborasi orangtua dengan konselor dalam mengembangkan sukses studi siswa. Jurnal Konseling Gusjigang, 3(1), 128-136.

Purwanto, N. (2006). Ilmu pendidikan teoritis dan praktis. Bandung: Rosdakarya.

Pemerintah Provinsi Daerah Khusus Ibukota Jakarta. (2004). Petunjuk pelaksanaan bimbingan konseling kurikulum 2004 provinsi DKI Jakarta. Jakarta: Pemprov DKI Jakarta.

Hidayat, D. R., \& Badrujaman, A. (2009). Cara mudah melakukan penelitian tindakan kelas. Jakarta: Trans Info Media.

Tohirin. (2007). Bimbingan dan konseling di sekolah dan madrasah. Jakarta: RajaGrafindo Persada.

Uno, H. B. (2011). Model pembelajaran, menciptakan proses belajar mengajar yang kreatif dan efektif. Jakarta: Bumi Aksara. 